\title{
A strategic framework for biodiversity monitoring in South African National Parks
}

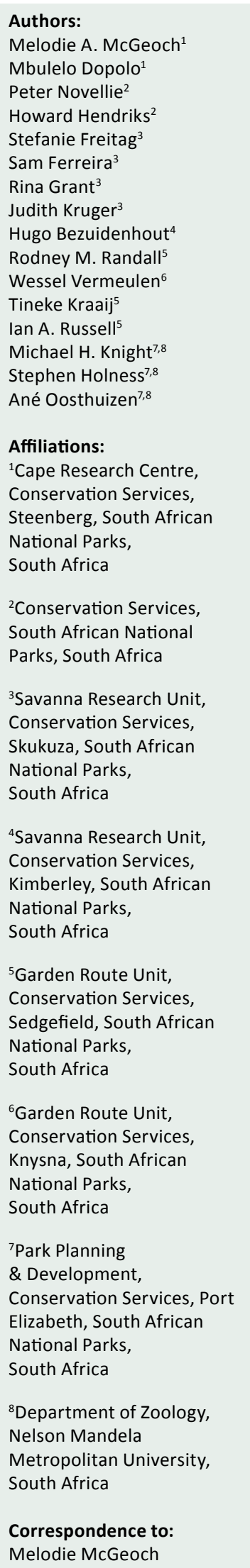

\begin{abstract}
Protected areas are under increasing threat from a range of external and internal pressures on biodiversity. With a primary mandate being the conservation of biodiversity, monitoring is an essential component of measuring the performance of protected areas. Here we present a framework for guiding the structure and development of a Biodiversity Monitoring System (BMS) for South African National Parks (SANParks). Monitoring activities in the organisation are currently unevenly distributed across parks, taxa and key concerns: they do not address the full array of biodiversity objectives, and have largely evolved in the absence of a coherent, overarching framework. The requirement for biodiversity monitoring in national parks is clearly specified in national legislation and international policy, as well as by SANParks' own adaptive management philosophy. Several approaches available for categorising the multitude of monitoring requirements were considered in the development of the BMS, and 10 Biodiversity Monitoring Programmes (BMPs) were selected that provide broad coverage of higher-level biodiversity objectives of parks. A set of principles was adopted to guide the development of BMPs (currently underway), and data management, resource and capacity needs will be considered during their development. It is envisaged that the BMS will provide strategic direction for future investment in this core component of biodiversity conservation and management in SANParks.
\end{abstract}

Conservation implications: Monitoring biodiversity in protected areas is essential to assessing their performance. Here we provide a coordinated framework for biodiversity monitoring in South African National Parks. The proposed biodiversity monitoring system addresses the broad range of park management plan derived biodiversity objectives.

\section{Introduction}

Protected areas in many parts of the world are under increasing threat from climate change, unsustainable resource use, system impoverishment (e.g. air pollution, encroachment), habitat conversion (e.g. roads, buildings) and isolation as a result of increasingly intense land use along their borders (Carey, Dudley \& Stolton 2000; Hansen \& DeFries 2007). For example, mammal populations in African protected areas (specifically eastern and western Africa) have declined significantly since the 1970 s (Craigie et al. 2010). Although mammal population abundances have generally been stable in southern Africa over the same time period (Craigie et al. 2010), pressures on ecosystem services in the region continue to grow, including the use of such services for fresh water, food and fuel (Van Jaarsveld et al. 2005). While many of the impacts of the pressures on ecosystem services are experienced outside of protected areas, protected areas themselves are not immune to the direct and indirect consequences of environmental change. Monitoring the status of, and threats to, biodiversity in protected areas is thus becoming increasingly important.

The measurement and monitoring of biodiversity in protected areas is generally aimed at, (1) assessing and improving the efficiency and effectiveness of conservation action, (2) informing management action and policy at both local and national levels, (3) providing evidence of conservation success and (4) strengthening the case for conservation among policy makers, funding agencies and land owners (Gaston et al. 2006). In addition, biodiversity monitoring systems in protected areas are intended to provide early recognition of unforeseen changes that impact on biodiversity, and to contribute to understanding potential impacts of current and new activities on biodiversity. These data will also feed into national and international assessments of the state of biodiversity (Buckley et al. 2008). Monitoring systems are thus necessary to both identify where policy or management intervention may be required, and to inform and evaluate the effectiveness of any interventions.

Monitoring is 'the collection and analysis of repeated observations or measurements to evaluate changes in condition and progress toward meeting a conservation or management objective' (Elzinga et al. 2001). Monitoring systems for assessing the effectiveness of the management of 


\section{Email:}

melodiem@sanparks.org

Postal address:

PO Box 216, Steenberg

7947 , South Africa

Dates:

Received: 29 Mar. 2010

Accepted: 04 Aug. 2010

Published: 13 May 2011

How to cite this article:

McGeoch, M.A., Dopolo,

M., Novellie, P., Hendriks,

H., Freitag, S., Ferreira,

S., Grant, R., Kruger, J.,

Bezuidenhout, H., Randall,

R.M., Vermeulen, W.,

Kraaij, T., Russell, I.A.,

Knight, M.H., Holness, S.

\& Oosthuizen, A., 2011, 'A

strategic framework for

biodiversity monitoring

in South African National

Parks', Koedoe 53(2),

Art. \#991, 10 pages.

doi:10.4102/koedoe.

v53i2.991

C 2011. The Authors Licensee: OpenJournals Publishing. This work is licensed under the Creative Commons protected areas broadly involves two approaches, (1) quantitative, measurement-based data collection obtained from in-field measurements (or, for example, from remote sensing) of some aspect of biodiversity or ecosystem process (a quantitative approach) and (2) qualitative, perception-based scoring of performance, conducted by managers and other stakeholders (i.e., a scoring approach) (Hockings 2003). Both scoring and quantitative approaches are valuable in the protected area context (Buckley et al. 2008). For example, the World Commission on Protected Areas Management Effectiveness Tracking Tool is a scoring system that is widely applied to protected areas across the world (Stolton et al. 2007). South African National Parks (SANParks) has also developed and implemented a scoring process, that is, State of Biodiversity (SoB) management reporting, that is used to assess how well management targets within SANParks are being met. It is used as a broad-based, qualitative assessment of the implementation of park objectives (Goodman 2003; Hockings, Leverington \& James 2006; Knight 2007). However, to date SANParks has not yet implemented a quantitative, biodiversity monitoring system that integrates biodiversity management objectives and activities within and across national parks.

Here we outline a framework for guiding the development and implementation of a SANParks Biodiversity Monitoring System (BMS). In this context, the term 'biodiversity' includes all levels of the biological hierarchy, from genes to ecosystems, and includes structure, function and composition (Gaston 1996; Noss 1990). It thus encompasses quantitative monitoring of not only the elements, but also the processes and mechanisms that generate, maintain and threaten biodiversity. As such, this framework provides, (1) the rationale for developing a SANParks BMS, (2) the organisational, national and international contexts within which the BMS is positioned, (3) an overview of the current status of biodiversity monitoring in SANParks, (4) an overarching structure and set of objectives for the BMS and (5) guiding principles and requirements for the development of monitoring programmes. Stages in the development of a BMS and the monitoring programmes that constitute it include scoping, design, testing and implementation phases, and the feedbacks between them (Mace et al. 2005; Reyers \& McGeoch 2007; The Royal Society 2003). The strategic framework presented here thus represents part of the scoping and design phase of a monitoring system for SANParks.

\section{Context}

SANParks' monitoring system must be cognisant of national and international biodiversity monitoring systems and programmes, while simultaneously focusing on the organisation's own mandate and management objectives (Reyers \& McGeoch 2007). Explicitly demonstrating how the SANParks BMS fits within the broader context, as far as is relevant, will ensure that monitoring retains a distinct profile within the organisation, and that it remains relevant and in line with global biodiversity monitoring standards.

SANParks' obligation to monitor is specified in the National Environmental Management: Protected Areas Act (Republic of South Africa 2003, Act 57 of 2003), in part, as: 'The management authority of a protected area must monitor the area against the indicators set in terms of established indicators for monitoring performance'. The performance indicators relate to, (1) the management of protected areas and (2) the conservation of biodiversity in those areas. The National Environmental Management: Biodiversity Act (Republic of South Africa, 2004, Act 10 of 2004) specifies that the requirements for biodiversity management are aimed at ensuring the long-term survival in nature of species or ecosystems and includes provision for the responsible person, organisation or organ of state to monitor and report on progress with such objectives.

South Africa has some history of environmental and biodiversity assessment, for example, the National State of the Environment Report (DEAT 2006), the National Environmental Indicators Programme (DEAT 2002), the National State of Forests Report (DWAF 2007) and the South African Environmental Observation Network (Van Jaarsveld et al. 2007). Further, in keeping with our commitments under the Convention on Biological Diversity (CBD), South Africa has developed a National Biodiversity Strategy and Action Plan and a National Biodiversity Framework (DEAT 2005). The National Biodiversity Monitoring Framework, together with the National Spatial Biodiversity Assessment (Driver et al. 2005) and the National Protected Areas Expansion Strategy (DEAT 2008), form the basis for the National Biodiversity Framework. SANParks' BMS aligns closely with these national initiatives, and will therefore be in a position to inform national reporting on biodiversity (Grobler 2009). 
Relevant international monitoring initiatives include, for example, those reporting on various targets set by the CBD (e.g., the 2010 Biodiversity Target, to achieve a significant reduction in the rate of biodiversity loss [Butchart et al. 2010; Walpole et al. 2009]). Relating specifically to protected areas, the CBD Programme of Work on Protected Areas outlines clear goals and targets for protected areas. For example, Goal 4.3 of this programme is 'to assess and monitor protected area status and trends' (UNEP-WCMC 2008). The CBD's Programme of Work on Marine and Coastal Biological Diversity also provides an overview of status and trends, and highlights the 2010 sub-targets for marine and coastal biodiversity.

Other national protected area agencies have also adopted quantitative biodiversity monitoring systems, such as Parks Canada's ecological integrity monitoring framework (Timko \& Innes 2009). Australian protected areas have clear monitoring strategies linked to management plans, although monitoring remains largely decentralised to individual parks (Buckley et al. 2008). By contrast, in the United Kingdom, the absence of systematically collected data in protected areas is currently considered to be a substantial hurdle to assessing their effectiveness (Gaston et al. 2006).

There are therefore clear international and national imperatives for monitoring the state of, and trends in, biodiversity, together with the success of management actions aimed at its conservation. As a significant role player in South Africa's biodiversity and conservation sector, SANParks' involvement in assessing the conservation and management of biodiversity in the context of the performance of protected areas is fundamental to the purpose of the organisation (SANParks 2006a). SANParks' strategic business is underpinned by the principles of adaptive management, that is, 'a management philosophy that places emphasis on strong goal-setting, integration of design, management and systematic monitoring in order to adapt and learn' (Biggs \&
Rogers 2003). As part of the adaptive management system, each park has a management plan (submitted to the Minister of Water and Environmental Affairs) that outlines a series of higher-level biodiversity objectives. These objectives provide broad foci for the rationale and design of a BMS for SANParks (Table 1).

\section{Current status}

Monitoring is one of the pillars underpinning SANParks' Strategic Adaptive Management (SAM) approach, where strongly goal-orientated park objective hierarchies are used to link science, monitoring and management (Biggs \& Rogers 2003). Monitoring, or 'regular state-of-the-system measurement', is pivotal to the success of SAM (Biggs \& Rogers 2003). SANParks has a long history of biodiversity monitoring, with several existing biodiversity monitoring projects and activities (Bryden \& De Vos 1994; Durrheim 2009). Over 170 current and historical SANParks projects qualify as either monitoring projects or research projects that provide relevant baseline information for monitoring. Together with SANParks scientists, external agencies and researchers have made a significant contribution to this body of work, specifically to understanding ecosystem processes, compiling species inventories and conducting species-specific studies (Bryden \& De Vos 1994). These monitoring-relevant projects encompass a spectrum of individual researcher and organisational involvement and data ownership arrangements. In a number of instances, therefore, the data lie with external organisations and are not necessarily effectively integrated into SANParks' knowledge systems and management processes. In addition, little biodiversity monitoring and reporting (quantitative, rather than score-based) currently occurs at either biodiversity estate (i.e., the full suite of biodiversity and ecosystems under SANParks management), regional or organisational levels (Figure 1). Investment in monitoring has also been unevenly distributed across environments and parks (as has research

TABLE 1: Current, higher level biodiversity objectives common to Park Management Plans (March 2008) that form the basis for identifying monitoring requirements.

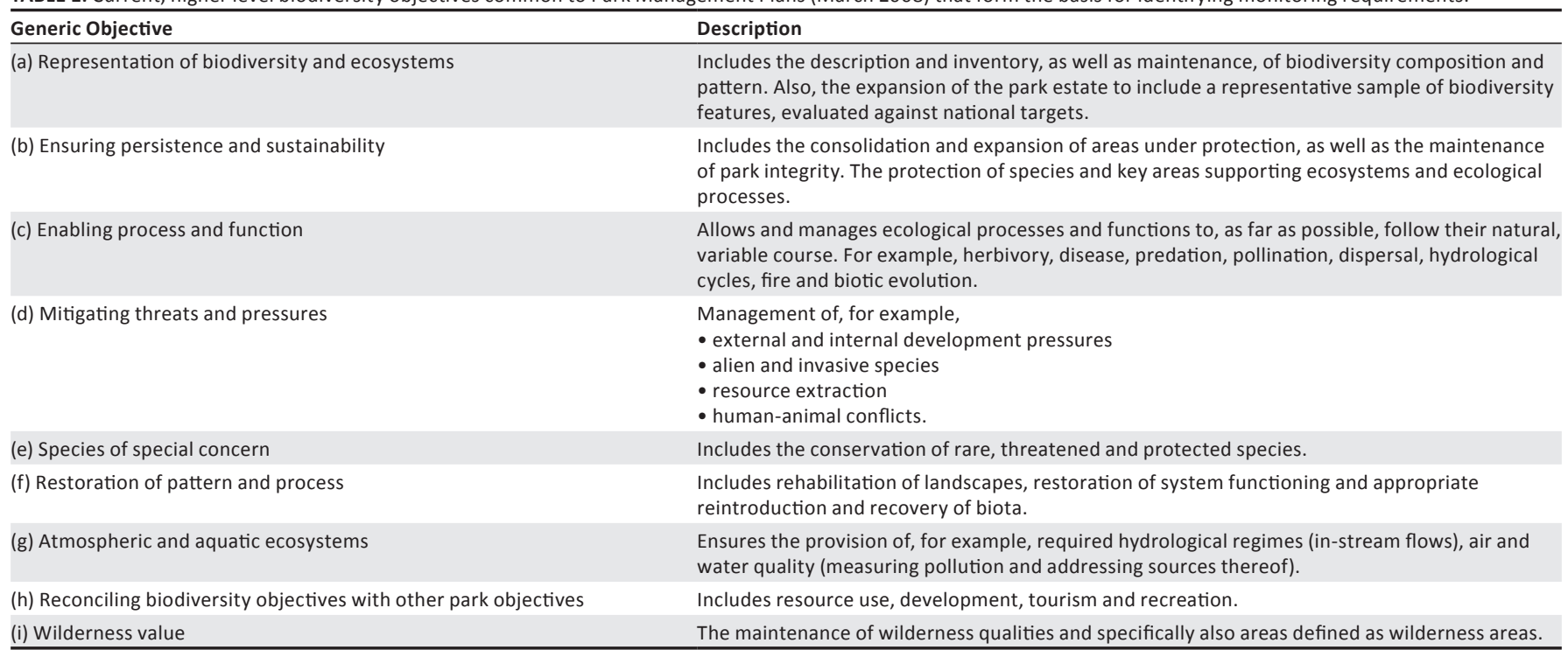


more generally, Bryden \& De Vos 1994). In most instances monitoring projects are designed for specific parks and in a few cases, for park clusters. This, in part, reflects the history of the organisation and the adoption and proclamation of new terrestrial parks and also marine protected areas.

Existing monitoring activities have thus developed independently of an integrated organisational monitoring framework, and many of them are not necessarily well linked to park management requirements. Furthermore, few existing monitoring activities are directly linked to management objectives via, for example, specific Thresholds of Potential Concern (TPCs, see Figure 1) (for TPC examples, see Foxcroft 2009 [alien species]; Rogers and O'Keefe 2003 [rivers]; Van Wilgen, Biggs \& Potgieter 1998 [fire]). Time series information is also limited to selected taxa (mostly mammals) and specific parks, for example, the Kruger National Park (Du Toit 2003). The alignment between research projects and SANParks' biodiversity objectives (Table 1) is not always clear, and existing projects do not currently address the full range of biodiversity objectives in park management plans (see also Buckley et al. 2008; Kapos et al. 2008). For example, the rehabilitation of degraded areas is an important management objective in several parks, particularly more recently proclaimed parks (such as fynbos in plantation exit areas in the Garden Route National Park), but it is currently largely not monitored. By contrast, sustainable indigenous forest monitoring in the Garden Route National Park is well developed, and encompasses monitoring natural ecosystem changes and the effects of management activities (Durrheim 2009).

The design of a BMS for SANParks must therefore be led by strategic organisational objectives, rather than by existing monitoring activities. Several gaps exist, and stronger alignment with park and organisational objectives is required (Buckley et al. 2008). Motivation for biodiversity monitoring is significantly strengthened when diverse monitoring objectives are placed within a coherent, overarching framework, such as that provided here. In addition to the absence of a strategic monitoring framework for the organisation, the most important reason to date for not implementing the required monitoring programmes has been the severe shortage of resources, both in terms of numbers of people to carry out the fieldwork, as well as a lack of the skills required to carry out extensive biodiversity surveys and associated data analyses (Field et al. 2007). The situation outlined here, while recognised as undesirable, is not uncommon to national protected area systems (e.g., Australia [Buckley et al. 2008] and the United Kingdom [Kapos et al. 2008]). Nonetheless, it provides the principle motivation for the development and implementation of a BMS for SANParks that addresses and prioritises the full range of key biodiversity concerns, conservation, and reporting commitments and obligations across parks, taxa and environments.

\section{Sanparks' biodiversity monitoring system}

Monitoring systems must be objective driven, and the rationale for a particular monitoring programme can be expressed as a series of multiple, hierarchical objectives (Field et al. 2007). There are many ways of categorising monitoring objectives, for example, by taxon or by threat, by management objective, or by the scale at which the monitoring programme will operate. While there is no universally best way of doing so, grouping monitoring objectives is a critical first step in rationalising the inevitable multitude of monitoring requirements (Regan et al. 2008). Different approaches to categorising monitoring objectives are usually complementary, and two main approaches (described below) were used to guide the design and development of

\begin{tabular}{|c|c|c|c|}
\hline $\begin{array}{l}\text { Level of } \\
\text { monitoring objective }\end{array}$ & & Objective & $\begin{array}{l}\text { Indicators and tools } \\
\text { for monitoring }\end{array}$ \\
\hline $\begin{array}{c}\uparrow \\
\text { Organisational effectiveness }\end{array}$ & $\rightarrow$ & $\begin{array}{c}\text { To leverage political will and change } \\
\text { organisational policy }\end{array}$ & $\begin{array}{l}\text { For example, global biodiversity } \\
\text { indicators and those in the National } \\
\text { Biodiversity Monitoring Strategy }\end{array}$ \\
\hline $\begin{array}{l}\text { Biodiversity estate } \\
\qquad \uparrow\end{array}$ & $\rightarrow$ & $\begin{array}{c}\text { To assess organisational } \\
\text { performance and biodiversity } \\
\text { nationally }\end{array}$ & $\uparrow$ \\
\hline Region/Biome & $\rightarrow$ & $\begin{array}{c}\text { To assess regional state/trends and } \\
\text { threats to biodiversity }\end{array}$ & \\
\hline Park & $\rightarrow$ & $\begin{array}{l}\text { To assess local state/trends and } \\
\text { threats to biodiversity within a park }\end{array}$ & $\begin{array}{c}\text { For example, Thresholds of Potential } \\
\text { Concern }\end{array}$ \\
\hline
\end{tabular}

Most of SANParks' current biodiversity monitoring activities are at park level. Vertical arrows illustrate scaling and integration of objectives and indicators. The 'biodiversity estate' is the sum total of the area and its biodiversity, managed by SANParks. Thresholds of Potential Concern (TPCs) are a monitoring endpoint tool that define the upper and lower levels along a continuum of change in selected environmental indicators, and form the operational goals of a park's objective hierarchy (Biggs \& Rogers 2003).

FIGURE 1: The SANParks Biodiversity Monitoring System (BMS) will address objectives at several levels: organisational, biodiversity estate, regional and park-specific. 
the SANParks BMS and to identify Biodiversity Monitoring Programmes (BMPs) (Figure 2).

Firstly, the BMS was primarily designed to encompass the monitoring of key organisational biodiversity management objectives at various scales and across national parks. Table 1 provides a synthesis of the range of higher-level management objectives extracted from SANParks' Park Management Plans (SANParks 2008). All protected areas managed by SANParks explicitly have biodiversity as a management objective, and most include biodiversity representation, process and sustainability in their objective hierarchies. The similarity of broad objectives across parks means that monitoring programmes may be identified and designed that are applicable to more than a single park. This approach has the following advantages, (1) it provides comparative information on the status of, and trends in, biodiversity across parks, (2) it provides information on the biodiversity estate and facilitates the interpretation of monitoring outcomes within a biome and regional context (Figure 1) and (3) it is more efficient than repeated, parallel investment in the development of monitoring programmes for individual parks.

Secondly, the BMS for SANParks must necessarily encompass multiple objectives at different levels and different scales. For example, the following three objectives are hierarchically related, (1) to monitor the effectiveness of SANParks in conserving rare and threatened species (organisational level objective), (2) to monitor changes in the conservation status of species of special concern in the fynbos biome (biodiversity estate/regional level objective) and (3) to monitor changes in the conservation status of bontebok in Bontebok National Park (park level objective) (as shown in Figure 1). These levels (organisational, estate, regional and park) do not necessarily form discrete categories, but do illustrate the hierarchical nature of monitoring needs and objectives (Figure 1).

\section{Biodiversity monitoring programmes}

The SANParks BMS comprises a series of BMPs (Figure 2). A monitoring programme encompasses one or more objectives with a common underlying rationale and usually more than a single measure or indicator (Heink \& Kowarik 2010). Together, the set of programmes (i.e. the monitoring system) addresses the broad range of SANParks' biodiversity monitoring priorities (Figure 3).

Ten BMPs have been identified for development and implementation. The identification and selection of these programmes took place at a workshop attended by 20 SANParks scientists in October 2009, following the development and adoption of the Biodiversity Monitoring Framework (2008-2009, presented here) (Figure 2 and Table 2). After discussion of the need to group or categorise monitoring requirements, and the various models and approaches available for doing so, a list of monitoring programmes was compiled by soliciting proposals from all scientists present. This list was then examined and related proposals merged, resulting in a final list of 10 programmes

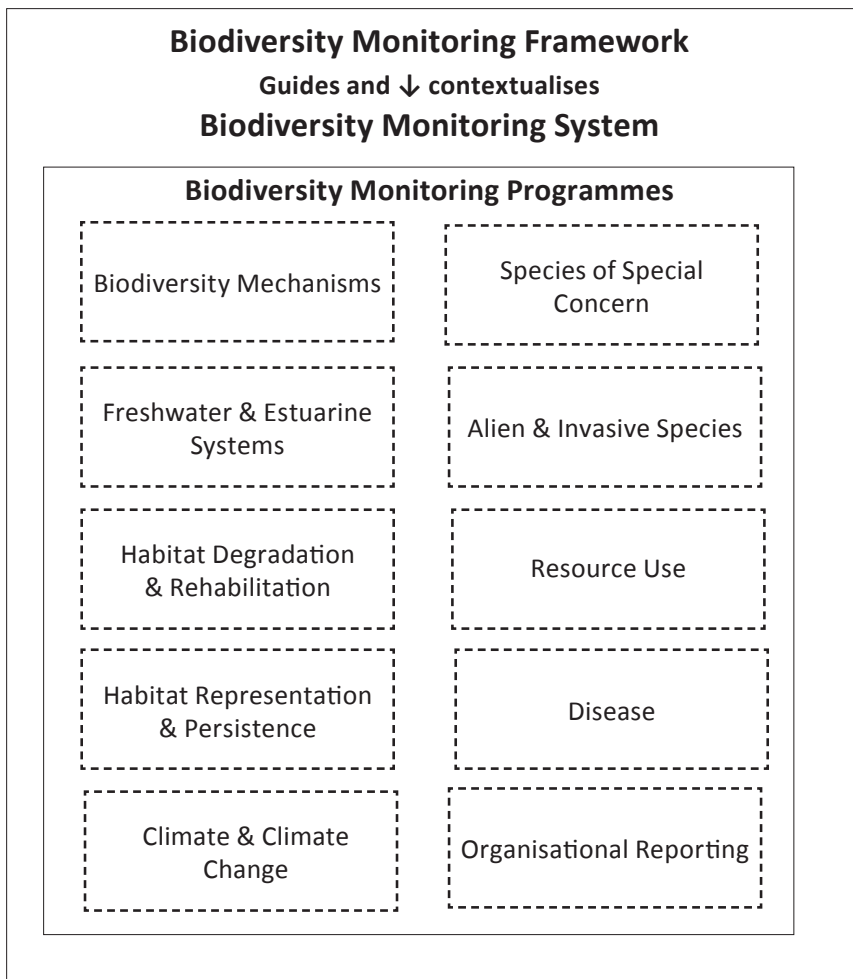

FIGURE 2: SANParks' Biodiversity Monitoring System (BMS) is composed of a number of Biodiversity Monitoring Programmes (BMPs); the 10 Biodiversity Monitoring Programmes shown here are those that have been identified for development and adoption.

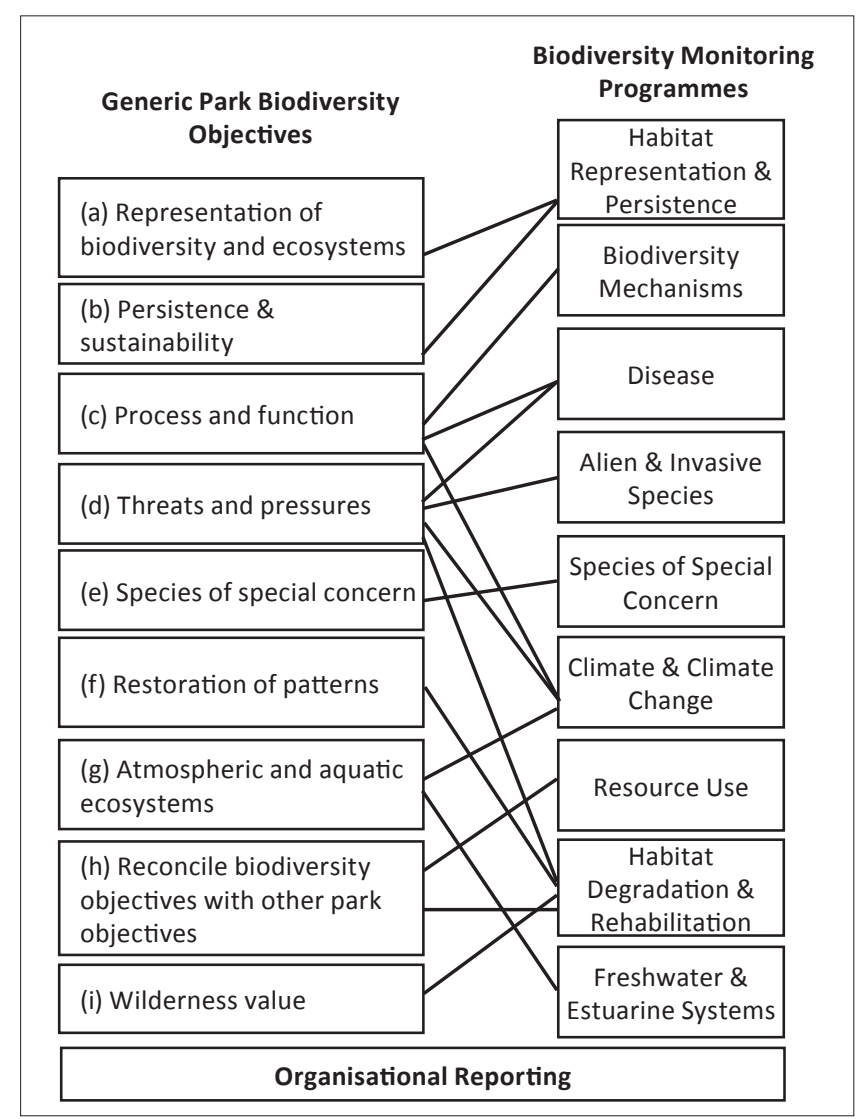

Only selected primary linkages are shown to illustrate broad and multiple coverage of objectives by monitoring programmes. The Organisational Reporting Programme is broadly relevant to all objectives and draws on selected elements of other monitoring programmes.

FIGURE 3: Relationship between biodiversity management objectives (left) and Biodiversity Monitoring Programmes (right). 
(Table 2). The list was then put to a vote to prioritise the programmes and potentially reduce their number. However, although there were wide-ranging views on the relative priorities of the programmes, there was consensus that, together, the 10 programmes encompass priority monitoring needs within SANParks. The number of programmes to be developed and adopted thus remained 10 .

The 10 programmes align strongly with park management objectives and are also strongly interrelated (Figure 3). For example, the Freshwater and Estuarine Systems Programme may rely on the Alien and Invasive Species Programme for alien monitoring in freshwater systems. The Habitat Degradation and Rehabilitation Programme and the Habitat Representation and Persistence Programme may work together, for example, on the impacts of adjacent land use on the park. The Climate and Climate Change Programme, in addition to its value in its own right, has the potential (via collation and reporting of weather and climate data) to support most other programmes. This interrelatedness between programmes, and the explicit integration of their design and outputs, is essential to maximise the knowledge gained and to achieve broader and more robust insights into ecosystem change (Biggs 2003; Buckland et al. 2005; Henry et al. 2008; Nielsen et al. 2009). Indeed, information generated by the BMS is designed to be integrated within and across both parks and programmes. Such integration will not only add value to the BMS, but will also streamline individual programmes and avoid duplication of effort. Although one of the 10 programmes selected is environment-specific (the Freshwater and Estuarine System Programme), terrestrial, freshwater and marine environments are integral to all programmes. Similarly, most programmes are likely to encompass the monitoring of a cross-section of taxa.

Each BMP will be designed to adopt, as far as possible, relevant, common approaches, methods and reporting systems across parks. Information generated by BMPs may be integrated (aggregated and disaggregated) and synthesised for reporting on the biodiversity status of individual parks, park clusters or all parks (Table 3 ). The system is also flexible, such that new programmes may be identified and introduced over time. The BMPs will be designed following a set of guiding principles (Table 3). These principles were adopted largely to ensure the relevance, efficiency, effectiveness and quality of the BMS. The programme design phase will be informed by subject and taxonomic expertise, as well as survey design, sampling design and statistical principles (e.g., Buckland et al. 2005; Elzinga et al. 2001; Field et al. 2007; Lovett et al. 2007) (Table 3). Programmes are intended for medium- to long-term adoption (over several 5-yearly park management plan revision cycles), and must therefore balance priority monitoring needs with logistic feasibility and sustainability. Existing monitoring projects and activities will, wherever feasible and appropriate, be integrated into one or more of the 10 programmes. In addition, where monitoring approaches have been developed and tested, or are widely used elsewhere, these may be adopted. For example, well developed sets of indicators exist for marine protected areas and marine ecosystems (Moloney \&
Shillington 2007; Pomeroy et al. 2005), as well as in the area of sustainable forest management (Durrheim 2009; DWAF 2005). Established systems such as these may, as appropriate, be adopted or modified for use in SANParks' BMS.

Each BMP will be formally proposed and independently reviewed prior to adoption. Programme proposals will include a description of context and rationale, objectives and methods, research and inventory needs, as well as a critical assessment of the strengths and weaknesses of the programme, and the indicators and measures that underpin it. Programme proposals will also include assessments of the capacity and funding requirements necessary to implement them, as well as assessments of relationships, overlaps and linkages between related programmes, and data management protocols. These BMP proposals serve several purposes, (1) they provide a means to solicit input, (2) they provide (in a single document) information that can be accessed readily and referenced, (3) they ensure continuity of implementation with staff changes and (4) they may be used to elicit support for the BMS (Elzinga et al. 2001). Finally, effective data management and reporting is also key to the success of monitoring systems such as this, and data management protocols will be fully integrated into the development of the BMS.

\section{Resource needs, capacity building and collaboration}

The greatest challenge facing conservation-relevant monitoring is balancing the development of appropriate strategies with personnel, time and budget constraints (Buckley et al. 2008; Walker 2009). In fact, the monitoring that is carried out in protected areas has been shown to be more strongly correlated with resource availability than any other factor (Bruner et al. 2001; WWF 2004). As outlined earlier, the assessment of resource and capacity needs will form part of the proposal development process for each BMP. Although existing resources, personnel and infrastructure will be used as far as possible, it is likely that a significant injection of both human and financial resources will be required for the SANParks BMS to be fully and effectively implemented. For example, the capacity for data management that is required by the BMS is far from sufficient to handle data from all 19 national parks. As is commonly the case elsewhere (Kapos et al. 2008), the implementation of biodiversity monitoring in SANParks is constrained by a lack of personnel tasked with and qualified to collect data, to manage and archive data, as well as to analyse and interpret data to inform management.

The inadequate state of resources for biodiversity monitoring in SANParks reflects a countrywide shortage of resources, as reported in South Africa's Fourth National Report to the CBD (DEAT 2009). This report notes a significant shortfall in funds required for the implementation of South Africa's National Biodiversity Framework, which includes the priority actions of developing national biodiversity research and monitoring strategies, as well as strategies to address the widespread shortage of human capital in the biodiversity 
TABLE 2: Biodiversity Monitoring Programmes (BMPs, see Figure 1), the rationale for their selection and the application of information generated by each programme.

\begin{tabular}{|c|c|}
\hline BM Programme & Rationale \\
\hline $\begin{array}{l}\text { 1. Biodiversity } \\
\text { mechanisms }\end{array}$ & $\begin{array}{l}\text { SANParks have as key mandate the maintenance of biological diversity. Most conservation actions take place } \\
\text { at site level with implementing decisions taken at park level. Conservation actions focus on providing the } \\
\text { opportunity for ecological processes to operate. If such processes are constrained, actions focus on restoring } \\
\text { or mimicking these. Conservation actions thus focus on managing drivers that directly influence conservation } \\
\text { objectives and specifically also those factors that modulate how drivers influence key objectives. Mechanisms } \\
\text { underpinning a conservation concern are thus the key focus of most site-based biodiversity management } \\
\text { actions. This programme will establish the mechanistic linkages between key conservation objectives for each } \\
\text { park, how drivers work and what modulates the effect of drivers explicitly. Heuristic models are used to guide the } \\
\text { identification and development of park-specific monitoring requirements across these linkages. }\end{array}$ \\
\hline
\end{tabular}

2. Species of special concern

3. Freshwater and estuarine systems

4. Alien and invasive species

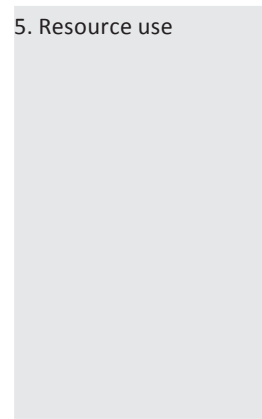

6. Habitat representation and persistence

7. Habitat degradation and rehabilitation

8. Disease

9. Climate and climate change

a

10. Organisational reporting
Particular species may be of special concern because they are threatened or their conservation status is in decline. Such species include local endemics and otherwise rare and threatened species (IUCN 2009). Species may be of particular conservation concern for other reasons, including their functional significance, common species experiencing rapid decline (Nielsen et al. 2009; Gaston 2010), or species occurring as disjunct populations in a specific area (see e.g. Geldenhuys 1992). Species loss from protected areas is a key measure of the performance of protected areas and of the effectiveness of conservation management more generally (Gaston et al. 2008).

Freshwater and estuarine systems are under intense pressure from increasing extraction as well as contamination from urban, agricultural and industrial return flows (Driver et al. 2005; Revenga et al. 2005; De Villiers \& Thiart 2007). Pressure on these systems is exacerbated by the climatic aridity of South Africa, along with climate change predictions that total annual precipitation in the region is likely to decrease (Schulze 2007).

Alien invasive species (IAS) are recognised as one the three principle threats to biodiversity, and both the number, extent and impact of IAS are increasing (Hulme 2009; McGeoch et al. 2010). Monitoring introduction pathways, new introductions, the spread of alien species within parks, and the success of management intervention is crucial to the successful management of this threat to biodiversity (Foxcroft 2009; Foxcroft et al. 2009).

There is a historical relationship between protected areas, their resources and stakeholders, particularly against the South African backdrop of land ownership, social segregation and restricted access to resources (Fabricius 2004; Von Maltitz \& Shackleton 2004). The purpose of sustainable resource use in national parks is to contribute to improved human well-being (Naughton-Treves et al. 2005). This includes encouraging people to manage their own resources better, and strengthening the links between human livelihoods, the value of conservation and sustainable resource use, with special attention to those peoples historically disadvantaged or marginalised by the South African protected area management authorities or their activities (SANParks 2008). Resource use in terrestrial and marine environments differ significantly in terms of their drivers, impact and management. For example, recreational fishing is a key form of resource extraction in the marine environment (Lombard et al. 2004) with high economic value (Leipold \& Van Zyl 2008). Some forms of resource use also currently generate income for parks (timber and wildlife sales). However, this objective must be carefully balanced with the overarching biodiversity objective of parks. Unsustainable, inappropriate and uncontrolled use of national park resources can result in adverse impacts on biodiversity and undermine the ecosystem integrity of parks.

Nationally, particular ecosystems may be of special concern because of their conservation status and poor level of protection within formal reserves (Driver et al. 2005). At a park level, the patterns and processes that support ecosystem functioning within the park are directly dependent on the persistence of biodiversity and processes in areas around the park (Hansen \& DeFries 2007). Key issues include the fragmentation of habitat, integrity of linkages and corridors between reserves and along gradients required for climate change adaptation, and the potential impacts of external park developments and activities.

This includes both the loss of habitat and decline in habitat quality as a consequence of, for example, inappropriate fire or herbivory regimes, alien species invasion, the loss of key biodiversity elements or ecosystem processes (Carey et al. 2000). In some instances it is possible to reverse the effects of habitat degradation via ecological restoration (e.g. recovery of wetlands from old agricultural land and post alien clearing rehabilitation). Monitoring the success of the latter is critical, particularly given protected area expansion in some cases into areas with a history of alternative land uses.

Disease is one of the natural complement of factors that affect plant and animal populations. However, human manipulation of plant and animal distributions, livestock and wildlife interfaces, and increasing individual stress as a consequence of declines in environmental quality all contribute to human-induced disease (Daszak et al. 2000; Bengis et al. 2003). The term 'emerging infectious diseases' (EIDs) is now used to describe the global phenomenon of increasing incidence of previously unknown diseases, and changes in the distribution of known diseases (Daszak et al. 2000). EIDs are thought to be driven by a combination of socio-economic and environmental factors (including, e.g., drug resistance and rainfall), and many EIDs are zoonotic and originate in wildlife (Jones et al. 2008). Disease therefore poses a significant potential threat to both the security of protected areas, and the health of their biota.

Climate plays a pivotal role as the basis for understanding biodiversity pattern and ecosystem processes (and thus often provides critical baseline data for other programmes listed here) (Bas et al. 2008; Lepetz et al. 2009). Globa climate change has significant implications for human well being and biodiversity conservation. In particular, questions are being asked about the role of protected areas in the face of climate change, the impacts on them and possible mitigation measures (Midgley et al. 2007; Schulze 2007).

Various biodiversity monitoring activities are more appropriately reported for the whole national park system managed by SANParks than for individual parks. This is often because of reporting requirements arising from legislation, national conservation programmes or international conventions. Examples are, (1) the contribution of the national park system towards national targets set for the conservation of threatened biomes or vegetation types and (2) the role of the national park system in protecting species that are of concern to Convention on International Trade in Endangered Species of Wild Fauna and Flora (CITES) as a result of international trade.
Application

Identify key concerns for

individual parks and as a result the relevant Thresholds of Potential Concern (see Figure 2) to be developed and implemented at a Park level. Inform park management and feed into and complement related monitoring programmes.

Inform management and feed into national reporting.

Inform park, provincial and national action and policy on freshwater management.

Inform policy and management and feed into national and international reporting.

Inform use and management of resources in parks and meet national reporting obligations on sustainable resource use.

Inform policy, development plans and management action.

Inform policy and management.

Inform national and organizational policy and park management.

Provide mechanistic basis for explaining trends in other indicators. Advise policy at national and organisational levels, and inform park management.

Meet reporting obligations and inform policy and management. 
TABLE 3: Principles guiding the development of the SANParks Biodiversity Monitoring System (BMS) and the Biodiversity Monitoring Programmes (BMPs) that it encompasses.

\begin{tabular}{|c|c|}
\hline \multicolumn{2}{|c|}{ Principle } \\
\hline 1. & $\begin{array}{l}\text { The BMS and Programmes that constitute it should be developed, where relevant, to align with and complement national and international monitoring systems } \\
\text { (Teder et al. 2007). }\end{array}$ \\
\hline 2. & $\begin{array}{l}\text { The BMS recognises that monitoring is required at multiple levels and scales and that monitoring objectives are often hierarchical. In this way, standard } \\
\text { approaches facilitate aggregation of information across ecosystems and into organisational, national and global measures (Teder et al. 2007). }\end{array}$ \\
\hline 3. & $\begin{array}{l}\text { Clear, rigorous and relevant sets of objectives, hypotheses and methods must be established for each monitoring programme (Nichols \& Williams 2006), with } \\
\text { feedbacks between scoping, design, testing and implementation phases (Reyers \& McGeoch 2007). }\end{array}$ \\
\hline 4. & $\begin{array}{l}\text { Monitoring programmes should be designed using best scientific practice and current understanding, and be supported by integrated, long-term and question- } \\
\text { driven research (Pringle \& Collins 2004; The Royal Society 2003; Nielsen et al. 2009). }\end{array}$ \\
\hline 5. & $\begin{array}{l}\text { Where possible and appropriate design monitoring programmes using well-established, widely applied techniques and methods, that capitalise on technological } \\
\text { developments (e.g., remote sensing, Margules et al. 2003; Soberon \& Peterson 2009). }\end{array}$ \\
\hline 6. & $\begin{array}{l}\text { Minimum monitoring requirements should initially be established independently of current capacity and resource constraints, whereafter cost-effectiveness } \\
\text { assessments, prioritisation and staged implementation options should be evaluated (Gardner et al. 2008). }\end{array}$ \\
\hline 7. & $\begin{array}{l}\text { Few, well-implemented monitoring programmes (including the indicators and thresholds of concern that underpin them) are preferable to many under-developed } \\
\text { programmes, or programmes that cannot be sustained because of capacity limitations (Biggs \& Rogers 2003; Timko \& Innes 2009). }\end{array}$ \\
\hline 8. & $\begin{array}{l}\text { Planning for analysis, reporting, data management, archiving and programme integration must be incorporated as essential elements during the design of the BMS } \\
\text { and its programmes (Spellerberg 2005; Field et al. 2007; Henry et al. 2008). This includes planning for the translation of results and outcomes into actions and advice } \\
\text { relevant to management and/or policy development, that is, to complete the adaptive management cycle. }\end{array}$ \\
\hline 9. & Monitoring programme proposals should be peer-reviewed prior to implementation, and thereafter should have regular review cycles. \\
\hline 10. & $\begin{array}{l}\text { The BMS will not necessarily exclude other monitoring activities (current or future), and additional monitoring with highly localised and perhaps shorter-term } \\
\text { objectives may be necessary. Where such activities and projects exist or are implemented, they will add value to and are likely to complement the BMS. However, } \\
\text { where possible, such activities should be integrated into the BMS. }\end{array}$ \\
\hline
\end{tabular}

sector. Nonetheless, as James, Gaston \& Balmford (2001) demonstrated, the cost of investing in conservation is small in comparison with the lost opportunities and environmental degradation in the absence of such investment (e.g., declining water quality, alien species invasion, human health costs of poor air quality). Biodiversity monitoring is essential to ensuring the effectiveness of this investment.

A further element critical to the success of the SANParks BMS is the continuation, strengthening and expansion of collaborative relationships with other agencies involved in biodiversity monitoring. This includes, for example, the South African National Biodiversity Institute, national departments, provincial conservation agencies, researchers and research organisations. The use of natural history societies, volunteer groups and citizen scientists in monitoring programmes has been shown to be highly effective, both internationally and in South Africa, with volunteers making significant contributions in this area (Bell et al. 2008; Braschler et al. 2010; Podjed \& Mursic 2008). The Honorary Rangers of SANParks is one such example, as are the citizen scientists that contribute to bird monitoring in South Africa and globally (see, e.g. www.adu.org.za).

\section{Evaluation, feedback and reporting cycles}

The approach that will be used to track and evaluate progress in the development and adoption of SANParks' BMS will be based on the evaluation and monitoring principles set for the organisation (SANParks 2006b). This approach adopts a logical series of steps to measure progress with the implementation of the BMS. It ensures ongoing assessment of the effectiveness of the framework and its implementation, and ultimately the organisation's mandate to enable informed and accountable decision-making through monitoring and analysis (Kapos et al. 2008). As part of this process, the BMS should be regularly reviewed and evaluated, as is the case with park management plans.

\section{Conclusion}

The Biodiversity Monitoring Framework presented here maps the way forward for biodiversity monitoring in SANParks. As such, it is intended to play a significant role in guiding investment in research, monitoring, and resulting policy and management action in national parks for the foreseeable future.

\section{Acknowledgements}

We thank the many members of the SANParks Conservation Services Division that contributed at various stages during the development of this framework, as well as Steven Chown, Dian Spear and Tony Rebelo for discussions and comments.

\section{References}

Bas, Y., Devictor, V., Moussus, J.P. \& Jiguet, F., 2008, 'Accounting for weather and time-of-day parameters when analysing count data from monitoring programs', Biodiversity and Conservation 17, 3403-3416. doi:10.1007/s10531-008-9420-6

Bell, S., Marzano, M., Cent, J., Kobierska, H., Podjed, D., Vandzinskaite, D., et al., 2008, 'What counts? Volunteers and their organisations in the recording and monitoring of biodiversity', Biodiv

Bengis, R.G., Grant, R. \& De Vos, V., 2003, 'Wildlife diseases and veterinary controls: A savanna ecosystem perspective', in J.T. du Toit, K.H. Rogers \& H.C. Biggs (eds.), The Kruger experience: Ecology and management of savanna heterogeneity, $\mathrm{pp}$. 349-369, Island Press, Washington.
34

Biggs, H.C., 2003, 'Integration of science: successes, challenges, and the future', in J.T. du Toit, K.H. Rogers \& H.C. Biggs (eds.), The Kruger experience: Ecology and management of savanna heterogeneity, pp. 469-487, Island Press, Washington.

Biggs, H.C. \& Rogers, K.H., 2003, 'An adaptive system to link science, monitoring, and management in practice', in J.T. du Toit, K.H. Rogers \& H.C. Biggs (eds.), The Kruger experience: Ecology and management of savanna heterogeneity, pp. 59-80, Island Press, Washington.

Braschler, B., Mahood, K., Karenyi, N., Gaston, K.J. \& Chown, S.L., 2010, 'Realizing a synergy between research and education: how participation in ant monitoring synergy between research and education: how participation in ant monitoring
helps raise biodiversity awareness in a resource-poor country', Journal of Insect helps raise biodiversity awareness in a resource-poor countr
Conservation 14, 19-30. doi:10.1007/s10841-009-9221-6

Bruner, A.G., Gullison, R.E., Rice, R.E. \& Da Fonseca, G.A.B., 2001, 'Effectiveness of parks in protecting tropical biodiversity', Science 291, 125-128. doi:10.1126/ science.291.5501.125, PMid:11141563

Bryden, H.B. \& De Vos, V., 1994, 'A scientific bibliography on the national parks of South Africa', Koedoe, suppl. 1994.

Buckland, S.T., Magurran, A.E., Green, R.E. \& Fewster, R.M., 2005, 'Monitoring change in biodiversity through composite indices', Philosophical Transactions of the in biodiversity through composite indices', Philosophical Transactions of the
Royal Society B 360, 243-254. doi:10.1098/rstb.2004.1589, PMid:15814343, Royal Society
PMCid: 1569463 
Buckley, R., Robinson, J., Carmody, J. \& King, N., 2008, 'Monitoring for management of conservation and recreation in Australian protected areas', Biodiversity and of conservation and recreation in Australian protected areas',
Conservation 17, 3589-3606. doi:10.1007/s10531-008-9448-7

Butchart, S.H.M., Walpole, M., Collen, B., van Strien, A., Scharlemann, J.P.W., Almond, R.E.A., et al., 2010, 'Global biodiversity: indicators of recent declines', Science 328, 1164-1168. doi:10.1126/science.1187512, PMid:20430971

Carey, C., Dudley, N. \& Stolton, S., 2000, Threats to protected areas. Squandering paradise? The importance and vulnerability of the world's protected areas, World Wide Fund for Nature International, Gland, Switzerland.

Craigie, I.D., Baillie, J.E.M., Balmford, A., Carbone, C., Collen, B., Green, R.E. \& Hutton, J.M., 2010, 'Large mammal population declines in Africa's protected areas', J.M., 2010, 'Large mammal population declines in Africa's protected a
Biological Conservation 143, 2221-2228. doi:10.1016/j.biocon.2010.06.007

Daszak, P., Cunningham, A.A. \& Hyatt, A.D., 2000, 'Emerging infectious diseases of wildlife - threats to biodiversity and human health', Science 287, 443-449. doi:10.1126/science.287.5452.443, PMid:10642539

Department of Environmental Affairs and Tourism (DEAT), 2002, Environmental Indicators for National State of the Environment Reporting South Africa, Department of Environmental Affairs and Tourism, South African Government, Pretoria.

Department of Environmental Affairs and Tourism (DEAT), 2005, South Africa's National Biodiversity Strategy and Action Plan, Department of Environmental National Biodiversity Strategy and Action Plan, Depart,
Affairs and Tourism, South African Government, Pretoria.

Department of Environmental Affairs and Tourism (DEAT), 2006, South African Environment Outlook. A report on the state of the environment, Department of Environmental Affairs and Tourism, South African Government, Pretoria.

Department of Environmental Affairs and Tourism (DEAT), 2008, National Protected Area Expansion Strategy, Department of Environmental Affairs and Tourism, South African Government, Pretoria.

Department of Environmental Affairs and Tourism (DEAT), 2009, South Africa's Fourth National Report to the Convention on Biodiversity, March 2009, South African National Report to the Convention on Biodiversity, March 2009,
National Biodiversity Institute, South African Government, Pretoria.

Department of Water Affairs and Forestry (DWAF), 2005, 'Achieving sustainable forest management: The principles, criteria, indicators and standards framework', $A$ Guide for Forest Managers \& Auditors to Achieve Sustainable Forest Management, Department of Water Affairs and Forestry, South African Government, Pretoria.

Department of Water Affairs and Forestry (DWAF), 2007, South Africa's State of the Forests Report 2004-2006, Department of Water Affairs and Forestry, South African Government, Pretoria.

De Villiers, S. \& Thiart, C., 2007, 'The nutrient status of South African rivers: Concentrations, trends and fluxes from the 1970s to 2005', South African Journal of Science 103, 343-349.

Driver, A., Maze, K., Lombard, A.T., Nel, J., Rouget, M., Turpie, J.K., et al., 2005, 'National spatial biodiversity assessment 2004: Priorities for biodiversity conservation in South Africa', Strelitzia 17, South African National Biodiversity Institute, Pretoria.

Durrheim, G.P., 2009, 'Monitoring for sustainable forest management in the Garden Route', South African National Parks, Scientific Services, Knysna.

Du Toit, J., 2003, 'Large herbivores and savanna heterogeneity', in J.T. Du Toit, K.H. Rogers \& H.C. Biggs (eds.), The Kruger experience: Ecology and management of savanna heterogeneity, pp. 292-309, Island Press, Washington.

Du Toit, J.T., Rogers, K.H. \& Biggs, H.C. (eds.), 2003, The Kruger experience: Ecology and management of savanna heterogeneity, Island Press, Washington.

Elzinga, C.L., Salzer, D.W., Willoughby, J.W. \& Gibbs, J.P., 2001, Monitoring plant and animal populations, Blackwell Science, Oxford.

Fabricius, C., 2004, 'The fundamentals of community-based natural resource management', in C. Fabricius, E. Koch, H. Magome \& S. Turner (eds.), Rights, resources and rural development: Community-based natural resource management in Southern Africa, pp. 3-43, Earthscan, London.

Field, S.A., O'Connor, P.J., Tyre, A.J. \& Possingham, H.P., 2007, 'Making monitoring meaningful', Austral Ecology 32, 485-491. doi:10.1111/j.1442-9993.2007.01715.x

Foxcroft, L.C., 2009, 'Developing thresholds of potential concern for invasive alien species: Hypotheses and concepts', Koedoe 51, 11-16. doi:10.4102/koedoe. v51i1.157

Foxcroft, L.C., Richardson, D.M., Rouget, M. \& MacFadyen, S., 2009, 'Patterns of alien plant distribution at multiple spatial scales in a large national park: implications for ecology, management and monitoring', Diversity and Distributions 15, 367-378. doi:10.1111/j.1472-4642.2008.00544.x

Gardner, T.A., Barlow, J., Araujo, I.S., Avila-Pires, T.C., Bonaldo, A.B., Costa, J.E., et al., 2008, 'The cost-effectiveness of biodiversity surveys in tropical forests', Ecology Letters 11, 139-150.

Gaston, K.J., 1996, Biodiversity: A biology of numbers and difference, Blackwell Science, Oxford.

Gaston, K.J., 2010, 'Valuing common species', Science 327, 154-155. doi:10.1126/ science.1182818, PMid:20056880

Gaston, K.J., Charman, K., Jackson, S.F., Armsworth, P.R., Bonn, A., Briers, R.A., et al., 2006, 'The ecological effectiveness of protected areas: The United Kingdom', Biological Conservation 132, 76-87. doi:10.1016/j.biocon.2006.03.013

Gaston, K.J., Jackson, S.F., Cantú-Salazar, L. \& Cruz-Piñón, G., 2008, 'The ecological performance of protected areas', Annual Review of Ecology, Evolution, and Systematics 39, 93-113. doi:10.1146/annurev.ecolsys.39.110707.173529

Geldenhuys, C.J., 1992, 'Disjunctions and distribution limits of forest species in the southern Cape', South African Forestry Journal 161, 1-13.

Goodman, P.S., 2003, 'Assessing management effectiveness and setting priorities in protected areas in KwaZulu-Natal', BioScience 53, 843-850. doi:10.1641/00063568(2003)053[0843:AMEASP]2.0.CO;2
Grobler, J., 2009, Biodiversity monitoring strategy and five-year action plan, Version 2, South African National Biodiversity Institute, Pretoria.

Hansen, A.J. \& DeFries, R., 2007, 'Ecological mechanisms linking protected areas to surrounding lands', Ecological Applications 17, 974-988. doi:10.1890/05-1098, PMid:17555212

Heink, U. \& Kowarik, I., 2010, 'What are indicators? On the definition of indicators in ecology and environmental planning', Ecological Indicators 10, 584-593. doi:10.1016/j.ecolind.2009.09.009

Henry, P.Y., Lengyel, S., Nowicki, P., Julliard, R., Clobert, J., Čelik, T. et al., 2008, 'Integrating ongoing biodiversity monitoring: potential benefits and methods', Biodiversity and Conservation 17, 3357-3382. doi:10.1007/s10531-008-9417-1

Hockings, M., 2003, 'Systems for assessing the effectiveness of management in protected areas', Bioscience 53, 823-832. doi:10.1641/0006in protected areas', BioScience
3568(2003)053[0823:SFATEO]2.0.CO;2

Hockings, M., Leverington, F. \& James, R., 2006, 'Evaluating management effectiveness', in M. Lockwood, G.L. Worboys \& A. Kothari (eds.), Managing protected areas: A global guide, pp. 635-655, Earthscan, London.

Hulme, P.E., 2009, 'Trade, transport and trouble: Managing invasive species pathways in an era of globalization', Journal of Applied Ecology 46, 10-18. doi:10.1111/ j.1365-2664.2008.01600.x

IUCN Standards and Petitions Working Group, 2009, Guidelines for Using the IUCN Red List Categories and Criteria, Version 7.0., prepared by the Standards and Petitions Working Group of the IUCN SSC Biodiversity Assessments Sub-Committee in Working Group of the IUCN SSC Biodiversity Assessments Sub-Committee in
August 2008, viewed 15 October 2009, from http://intranet.iucn.org/webfiles/ August 2008, viewed 15 October 2009,
doc/SSC/RedList/RedListGuidelines.pdf.

James, A., Gaston, K.J. \& Balmford, A., 2001, 'Can we afford to conserve biodiversity?', BioScience 51, 43-52. doi:10.1641/0006-3568(2001)051[0043:CWATCB]2.0.CO;2

Jones, K.E., Patel, N.G., Levy, M.A., Storeygard, A., Balk, D., Gittleman, J.L., et al., 2008, 'Global trends in emerging infectious diseases', Nature 451, 990-993. doi:10.1038/nature06536, PMid:18288193

Kapos, V., Balmford, A., Aveling, R., Bubb, P., Carey, P., Entwistle, A., et al., 2008, 'Calibrating conservation: New tools for measures of success', Conservation Letters 1, 155-164. doi:10.1111/j.1755-263X.2008.00025.X
Le

Knight, M.H., 2007, SANParks State of Biodiversity Report (SoB) Background Sheet: Park Planning \& Development, Conservation Services, unpublished report, SANParks, Port Elizabeth.

Leipold, M. \& Van Zyl, C.J., 2008, 'The economic impact of sport and recreational angling in the Republic of South Africa, 2007', Project Report, pp. 48, Development Strategies International, Cape Town.

Lepetz, V., Massot, M., Schmeller, D.S. \& Clobert, J., 2009, 'Biodiversity monitoring: some proposals to adequately study species' responses to climate change', Biodiversity and Conservation 18, 3185-3203. doi:10.1007/s10531-009-9636-0

Lombard, A.T., Strauss, T., Harris, J., Sink, K., Attwood, C. \& Hutchings, L., 2004, 'Marine Component', in South African National Spatial Biodiversity Assessment Technical Report, Chapter 4, South African National Biodiversity Institute, Pretoria.

Lovett, G.M., Burns, D.A., Driscoll, C.T., Jenkins, J.C., Mitchell, M.J., Rustad, L. et al., 2007, 'Who needs environmental monitoring?' Frontiers in Ecology and the
Environment 5, 253-260. doi:10.1890/1540-9295(2007)5[253:WNEM]2.0.CO;2

Mace, G.M., Delbaere, B., Hanski, I., Harrison, J.A., Novo, F.G., Pereira, H.M., et al., 2005, A user's guide to biodiversity indicators, European Academy of Sciences Advisory Council, The Royal Society, London.

Margules, C.R., Grant, C.C., Poon, E., Deacon, A., MacFadyen, S., Biggs, H.C., et al., 2003, A suggested biodiversity survey and monitoring program for Kruger National Park, Scientific Report 01/03, Scientific Services, Skukuza, Kruger National Park.

McGeoch, M.A., Butchart, S.H.M., Spear, D., Marais, E., Kleynhans, E.J., Symes, A., et al., 2010, 'Global indicators of biological invasion: species numbers, biodiversity j.1472-4642.2009.00633.x

Midgley, G.F., Chown, S.L. \& Kgope, B.S., 2007, 'Monitoring effects of anthropogenic climate change on ecosystems: A role for systematic ecological observation?', South African Journal of Science 103, 282-286.

Moloney, C.L. \& Shillington, F.A., 2007, 'Progress towards marine ecosystem observing systems in South Africa', South African Journal of Science 103, 301-305.

Naughton-Treves, L., Buck Holland, M. \& Brandon, K., 2005, 'The role of protected areas in conserving biodiversity and sustaining local livelihoods', Annual
Review of Environment and Resources 30, 219-252. doi:10.1146/annurev. Review of Environment
energy.30.050504.164507

Nichols, J.D. \& Williams, B.K., 2006, 'Monitoring for conservation', Trends in Ecology and Evolution 21, 668-673. doi:10.1016/j.tree.2006.08.007

Nielsen, S.E., Haughland, D.L., Bayne, E. \& Schieck, J., 2009, 'Capacity of large-scale, long-term biodiversity monitoring programmes to detect trends in species prevalence', Biodiversity and Conservation 18, 2961-2978. doi:10.1007/s10531009-9619-1

Noss, R.F., 1990, 'Indicators for monitoring biodiversity: A hierarchical approach', Conservation Biology 4, 355-364. doi:10.1111/j.1523-1739.1990.tb00309.x

Podjed, D. \& Muršič, R., 2008, 'Dialectical relations between professionals and volunteers in a biodiversity monitoring organisation', Biodiversity and and volunteers in a biodiversity monitoring organisation',
Conservation 17, 3471-3483. doi:10.1007/s10531-008-9443-z

Pomeroy, R.S., Watson, L.M., Parks, J.E. \& Cid, G.A., 2005, 'How is your MPA doing? A methodology for evaluating the management effectiveness of marine protected areas', Ocean \& Coastal Management 48, 485-502. doi:10.1016/j. ocecoaman.2005.05.004

Pringle, C.M. \& Collins, S.L., 2004, 'Needed: A unified infrastructure to support long-term scientific research on public lands', Ecological Applications 14, 18-21. doi:10.1890/03-5106 
Regan, H.M., Hierl, L.A., Franklin, J., Deutschman, D.H., Schmalbach, H.L., Winchell, C.S. et al., 2008, 'Species prioritization for monitoring and management in regional multiple species conservation plans', Diversity and Distributions 14, 462-471. doi:10.1111/j.1472-4642.2007.00447.x

Republic of South Africa, 2003, National Environmental Management: Protected Areas Act, 57 of 2003, Government Printer, Pretoria.

Republic of South Africa, 2004, National Environmental Management: Biodiversity Act, 10 of 2004, Government Printer, Pretoria.

Revenga, C., Campbell, I., Abell, R., De Villiers, P. \& Bryer, M., 2005, 'Prospects for monitoring freshwater ecosystems towards the 2010 targets', Philosophical Transactions of the Royal Society B 360, 397-413. doi:10.1098/rstb.2004.1595, PMid:15814353, PMCid:1569454

Reyers, B. \& McGeoch, M.A., 2007, 'A biodiversity monitoring framework for South Africa: Progress and directions', South African Journal of Science 103, 295-300.

Rogers, K.H. \& O'Keefe, J., 2003, 'River heterogeneity: Ecosystem structure, function and management', in J.T. du Toit, K.H. Rogers \& H.C. Biggs (eds.), The Kruger experience: Ecology and management of savanna heterogeneity, pp. 189-218, Island Press, Washington.

South African National Parks (SANParks), 2006a, South African National Parks Coordinated Policy Framework Governing Park Management Plans, SANParks, Pretoria, viewed 15 January 2010, from http://celtis.sanparks.org/conservation/ park_man/cpfjanuary2010.pdf

South African National Parks (SANParks), 2006b, South African National Parks Project Management Policy V1.2., Policy no. 13/1/P/01, South African National Parks, Pretoria.

South African National Parks (SANParks), 2008, South African National Parks Resource Use Policy, South African National Parks, Pretoria.

Schulze G.C., 2007, 'Atmospheric observations and numerical weather prediction', South African Journal of Science 103, 3180-322.

Statistics South Africa (SSA), 2008, South African Statistical Quality Assessment Framework (SASQAF), 1st edn., Statistics South Africa, Pretoria.

Stolton, S., Hockings, M., Dudley, N., MacKinnon, K., Whitten, T. \& Leverington, F., 2007, Reporting progress in protected areas: A site level management effectiveness tracking tool, 2nd edn., World Bank/WWF Forest Alliance, WWF, Gland, Switzerland.

Soberón, J. \& Peterson, A.T., 2009, 'Monitoring biodiversity loss with primary speciesoccurrence data: Toward national-level indicators for the 2010 target of the Convention on Biological Diversity', Ambio 38, 29-34. doi:10.1579/0044-744738.1 .29
Spellerberg, I.F., 2005, Monitoring ecological change, 2nd edn., Cambridge University Press, Cambridge. doi:10.1017/СВ09780511614699

Teder, T., Moora, M., Roosaluste, E., Zobel, K., Pärtel, M., Kõljalg, U., et al., 2007, 'Monitoring of biological diversity: A common-ground approach', Conservation Biology 21, 313-317. doi:10.1111/j.1523-1739.2006.00575.x, PMid:17391181

The Royal Society, 2003, Measuring biodiversity for conservation, Policy Document $11 / 03$, The Royal Society, London.

Timko, J.A. \& Innes, J.L., 2009, 'Evaluating ecological integrity in national parks: Case studies from Canada and South Africa', Biological Conservation 142, 676-688. doi:10.1016/j.biocon.2008.11.022

UNEP-WCMC, 2008, State of the world's protected areas: An annual review of global conservation progress, UNEP-WCMC, Cambridge.

Van Jaarsveld, A.S., Biggs, R., Scholes, R.J., Bohensky, E., Reyers, B., Lynam, T., et al., 2005, 'Measuring conditions and trends in ecosystem services at multiple scales: The Southern African Millennium Ecosystem Assessment (SAfMA) experience', The Southern African Millennium Ecosystem Assessment (SAfMA) experience,'
Philosophical Transactions of the Royal Society B 360, 425-441. doi:10.1098/ Philosophical Transactions of the Royal Society
rstb.2004.1594, PMid:15814355, PMCid:1569451

Van Jaarsveld, A.S., Pauw, J.C., Mundree, S., Mecenero, S., Coetzee, B.W.T. \& Alard, G.F., 2007, 'South African Environmental Observation Network: Vision, design and status', South African Journal of Science 103, 289-294.

Van Wilgen, B.W., Biggs, H.C. \& Potgieter, A.L.F., 1998, 'Fire management and research in the Kruger National Park, with suggestions on the detection of thresholds of potential concern', Koedoe 41, 69-87.

Von Maltitz, G.P., \& Shackleton, S.E., 2004, 'Use and management of forests and woodlands in South Africa: Stakeholders, institutions and processes from past to present', in M.J. Lawes, H.A.C. Eeley, C.M. Shackleton \& B.G.S. Geach (eds.), Indigenous forests and woodlands in South Africa: Policy, people and practice, pp. 109-135, University of KwaZulu-Natal Press, Durban.

Walker, K.L., 2009, 'Protected-area monitoring dilemmas: A new tool to assess success', Conservation Biology 23, 1294-1303. doi:10.1111/j.1523-1739.2009.01203.x, PMid:19765040

Walpole, M., Almond, R.E.A., Besançon, C., Butchart, S.H.M., Campbell-Lendrum, D., Carr, G.M., et al., 2009, 'Tracking progress toward the 2010 biodiversity target and beyond', Science 325, 1503-1504. doi:10.1126/science.1175466, PMid:19762630

World Wildlife Fund (WWF), 2004, 'Are protected areas working? An analysis of forest protected areas by WWF', World Wildlife Fund International, Gland, Switzerland. 